\title{
STRATEGI NAFKAH, KARAKTER SOSIO-BUDAYA DAN RELASI SOSIAL RUMAHTANGGA PENAMBANG BELERANG
}

\section{Livelihood Strategies, Socio-Culture Character and Social Relation of Sulfur Miners Household}

\author{
Muhammad Rifky Afqari ${ }^{1)}$ dan Arya Hadi Dharmawan ${ }^{2)}$
}

${ }^{1)}$ Departemen Sains Komunikasi dan Pengembangan Masyarakat, Fakultas Ekologi Manusia, Institut Pertanian Bogor, Darmaga Bogor 16680, Indonesia

Email: afqarir@gmail.com; adharma@apps.ipb.ac.id

\begin{abstract}
Mining is a buisness that is highly dependent on environmental conditions, climate, and policies are always changing every moment. Social and ecological changes happend more quickly so that the rural miner households in general are often faced with the uncertainties that can lead to vlunerability. Many livelihood systems are used by miner household to survive. In implementating the strategy, of living, miner households take advantage of the five assets or livelihood capital (natural capital, human capital, physical capital, financial capital, and social capital) to make a living strategy for the continuation of life. The purpose of this research is to find out how social capital especially social relation support livelihood structure of sulfur miners household in Tamansari Village, Banyuwangi District, East Java. This study used the quantitative approach using questioner instrument and qualitative approach through depth interview.
\end{abstract}

Keywords: miner household, livelihood assets, livelihood strategies, livelihood structure, social relation

\begin{abstract}
ABSTRAK
Usaha pertambangan merupakan usaha yang sangat bergantung pada kondisi lingkungan, iklim, dan kebijakan yang selalu berubah-ubah. Perubahan-perubahan sosial maupun ekologi tersebut terjadi semakin cepat sehingga rumahtangga penambang di pedesaan umumnya sering dihadapkan pada ketidakpastian yang dapat menimbulkan kerentanan. Berbagai strategi nafkah digunakan oleh rumahtangga penambang untuk dapat bertahan hidup. Dalam melaksanakan strategi nafkah, rumahtangga penambang memanfaatkan livelihood assets atau modal penghidupan (modal alam, modal manusia, modal fisik, modal finansial, dan modal sosial) untuk keberlangsungan hidup mereka. Penelitian ini bertujuan untuk mengetahui bagaimana modal sosial terutama relasi sosial mendukung struktur nafkah rumahtangga penambang belerang di Desa Tamansari, Kabupaten Banyuwangi, Jawa Timur. Penelitian ini menggunakan metode kuantitatif dengan pendekatan survei melalui instrumen kuesioner didukung dengan metode kualitatif melalui wawancara mendalam.
\end{abstract}

Kata kunci: rumahtangga penambang, modal nafkah, relasi sosial, strategi nafkah, struktur nafkah

\section{PENDAHULUAN}

Indonesia adalah negara yang secara potensial memiliki kekayaan alam berupa bahan tambang baik logam maupun non-logam. Negara ini memiliki hasil tambang yang melimpah di antaranya seperti emas, tembaga, batu bara, belerang, dan sebagainya. Potensi tersebut kemudian dimanfaatkan oleh manusia untuk berbagai kepentingan. Dengan demikian, manusia mampu memperoleh keuntungan dari aktivitas pemanfaatan hasil tambang tersebut. Manusia memanfaatkan sumber daya alam dengan banyak cara, baik dilakukan secara tradisional maupun modern. Akibatnya, banyak perusahaanperusahaan penambangan yang berdiri di wilayah yang kaya akan sumber daya alam tersebut. Barang tambang memang memiliki daya jual yang tinggi karena keberadaannya yang terbatas dan tidak dapat diperbaharui. Selain itu, hasil tambang juga mempunyai nilai guna yang tinggi dalam berbagai hal, misalnya dalam pembuatan bahan dasar untuk bangunan.

Kabupaten Banyuwangi merupakan bagian paling timur dari wilayah Provinsi Jawa Timur yang memiliki sumberdaya alam yang melimpah. Dari sekian banyak gunung yang ada di Banyuwangi, terdapat salah satu gunung yang masih bersifat aktif atau bisa disebut dengan gunung api, gunung tersebut adalah Gunung Ijen yang terletak di Kecamatan Licin, Kabupaten Banyuwangi, Provinsi Jawa Timur dimana di kecamatan ini terdapat beberapa dusun dengan sebagian besar masyarakatnya bekerja 
sebagai penambang belerang. Mereka melakukan penambangan di Kawah Ijen, yaitu kawah dari Gunung Ijen yang lokasinya tidak jauh dari kecamatan tersebut. Dataran tinggi ini masuk kedalam area Taman Nasional Alas Purwo (TNAP).

Menurut Ellis (2000), terdapat lima modal yang dapat dijadikan sebagai modal nafkah yaitu modal alam, modal fisik, modal finansial, modal manusia, dan modal sosial. Modal nafkah tersebut digunakan sebagai upaya untuk tetap bertahan dalam menghadapi berbagai perubahan sosial, ekonomi, maupun ekologi yang dapat mengancam sistem nafkah yang dimiliki oleh rumahtangga penambang belerang. Pemanfaatan modal sosial terutama jaringan atau relasi sosial yang dimiliki oleh rumahtangga penambang belerang dapat berkontribusi untuk membantu rumahtangga penambang dalam mencari jalan keluar saat terjadi kesulitan.

Pada umumnya untuk memenuhi kebutuhan, rumahtangga penambang memerlukan sumber nafkah yang beragam. Sumber nafkah akan menentukan struktur pendapatan penambang yang bisa terdiri dari sektor pertambangan dan nonpertambangan. Semakin banyak variasi nafkah, berarti penambang akan memiliki banyak sumber nafkah dari berbagai pekerjaan yang dilakukan. Pernyataan tersebut kemudian menimbulkan pertanyaan untuk mengetahui bagaimana pengaruh pemanfaatan modal nafkah atau livelihood assets terhadap ragam strategi nafkah yang dilakukan rumahtangga penambang belerang di Desa Tamansari, Kecamatan Licin, Kabupaten Banyuwangi?

Menambang adalah jenis mata pencaharian yang digeluti oleh mayoritas masyarakat Desa Tamansari. Dengan memanfaatkan sumberdaya alam yang telah tersedia, penambang melakukan aktivitas ekonomi untuk memiliki pendapatan agar dapat memenuhi kebutuhan hidup rumahtangganya. Menurut Dharmawan (2007) sumber nafkah rumahtangga sangat beragam karena rumahtangga tidak hanya bergantung pada satu pekerjaan, dan satu sumber nafkah juga tidak dapat digunakan untuk memenuhi seluruh kebutuhan rumahtangga. Hal ini menimbulkan pertanyaan bagaimana struktur dan strategi nafkah rumahtangga penambang belerang di Desa Tamansari, Kecamatan Licin, Kabupaten Banyuwangi?
Relasi sosial merupakan bagian dari modal sosial yang memiliki peran tersendiri bagi rumahtangga penambang dalam melakukan strategi untuk bertahan hidup. Semakin luas relasi atau jaringan yang dimiliki maka akan semakin memudahkan rumahtangga atau individu untuk meminta bantuan ketika sedang mengalami kesulitan ataupun krisis. Maka dari itu perlu diketahui bagaimana relasi sosial yang dibagun untuk membangun struktur nafkah rumahtangga penambang belerang di Desa Tamansari, Kecamatan Licin, Kabupaten Banyuwangi?

\section{PENDEKATAN TEORITIS}

\section{Strategi Nafkah dan Struktur Nafkah}

Strategi nafkah menurut Dharmawan (2001) adalah segala aktivitas maupun keputusan untuk bertahan hidup yang dipilih atau diambil oleh anggota rumah tangga agar hidupnya lebih baik lagi. Agar dapat mempertahankan hidupnya, rumah tangga biasanya tidak hanya menerapkan satu strategi nafkah melainkan menggabungkannya dari berbagai bentuk strategi nafkah. Merujuk pada Scoones (1998), klasifikasi strategi nafkah yang dilakukan oleh rumahtangga, diantaranya sebagai berikut:

1. Rekayasa sumber nafkah

Strategi nafkah dengan memanfaatkan sektor pertanian atau pertambangan secara efektif dan efisien melalui penambahan input eksternal seperti teknologi dan tenaga kerja (intensifikasi), dan strategi nafkah dengan memperluas lahan garapan (ekstensifikasi).

2. Pola nafkah ganda atau diversifikasi Strategi nafkah dengan menerapkan beragam pola nafkah dengan cara mencari pekerjaan lain di luar sektor pertambangan guna menambah pendapatan, atau dapat dengan cara menggerakkan tenaga kerja keluarga (ayah, ibu, anak) untuk ikut bekerja selain pertambangan.

3. Rekayasa spasial atau migrasi

Strategi nafkah yang dilakukan dengan keluar dari daerah desanya (mobilitas) ke daerah lain, baik secara permanen maupun sirkuler. Biasanya migrasi dilakukan karena lapangan pekerjaan yang tersedia di desa tidak sebanyak di kota. 


\section{Livelihood Assets}

Ellis (2000) mengemukakan bahwa terdapat lima modal dasar dalam livelihood assets, yaitu:

1. Modal Sumberdaya Alam (Natural Capital)

Modal ini bisa juga disebut sebagai lingkungan yang merupakan gabungan dari berbagai faktor biotik dan abiotik di sekeliling manusia yang dapat digunakan untuk membantu kelangsungan hidup.

2. Modal Fisik (Physical Capital)

Modal fisik merupakan modal yang berbentuk infrastruktur dasar atau merujuk pada aset-aset dalam proses produksi ekonomi, seperti alatalat, mesin, saluran irigasi, jalan, gedung, dan lain sebagainya.

3. Modal Manusia (Human Capital)

Modal ini merupakan modal yang ada dalam diri manusia. Modal ini berupa tenaga kerja yang tersedia dalam rumahtangga yang dipengaruhi oleh pendidikan, keterampilan, dan kesehatan untuk dapat memenuhi kebutuhan hidupnya.

4. Modal Finansial (Financial Capital and Subtitutes)

Modal ini berupa uang yang digunakan oleh suatu rumahtangga. Modal ini dapat berupa uang tunai, tabungan, ataupun akses dan pinjaman.

\section{Modal Sosial (Social Capital)}

Modal ini merupakan gabungan komunitas yang dapat memberikan keuntungan bagi individu atau rumahtangga yang tergabung di dalamnya. Contoh modal sosial adalah jaringan kerja (networking) yang merupakan hubungan vertikal maupun hubungan horizontal untuk bekerja sama dan memberikan bantuan untuk memperluas akses terhadap kegiatan ekonomi.

\section{Relasi Sosial}

Relasi sosial merupakan salah satu bagian dari modal nafkah, yaitu modal sosial. Relasi sosial adalah hubungan antarsesama di dalam suatu masyarakat. Menurut Astuti (2012) relasi sosial disebut juga sebagai hubungan sosial yang merupakan hasil dari interaksi antara dua orang atau lebih. Terdapat dua bentuk relasi sosial menurut Astuti (2012), yaitu relasi atau hubungan sosial assosiatif dan dissosiatif.
Relasi assosiatif ditunjukan dengan adanya kerja sama, akomodasi, asimilasi, dan akulturasi. Sedangkan relasi dissosiatif berbentuk oposisi atau persaingan, pertentangan, dan perselisihan.

\section{Kerangka Pemikiran}

Berbagai permasalahan yang dihadapi penambang belerang akan mempengaruhi tingkat pemanfaatan dan penguasaan sumberdaya yang dimiliki penambang, baik modal alam, fisik, manusia, finansial, dan sosial. Masing-masing modal nafkah tersebut dapat diukur dengan beberapa indikator. Berdasarkan penelitian Sembiring dan Dharmawan (2014), modal alam diukur berdasarkan penguasaan tanah dan akses terhadap tanah oleh rumahtangga. Modal fisiik diukur berdasarkan kepemilikan aset rumahtangga yang mendukung perekonomian rumahtangga, seperti gerobak, warung, dan sepeda motor. Modal manusia diukur berdasarkan tingkat pendidikan, alokasi tenaga kerja rumahtangga, keterampilan dan penggunaan tenaga kerja. Modal finanasial diukur berdasarkan dua hal yaitu tabungan dan pinjaman. Modal sosial diukur berdasarkan tiga aspek, yakni kepercayaan, jejaring, dan norma.

Strategi nafkah adalah cara yang dilakukan oleh kelompok atau masyarakat dalam memepertahankan ekonominya pada saat dilanda permasalahan, tidak terkecuali rumahtangga penambang. Strategi nafkah pada dasarnya terbagi terdiri dari strategi produksi (ekonomi) dan strategi non-produksi (pemanfaatan hubungan sosial), dimana strategi ekonomi meliputi pola nafkah ganda yaitu satu orang melakukan lebih dari satu pekerjaan untuk menghasilkan uang, optimalisasi tenaga kerja, dimana suatu rumahtangga memanfaatkan seluruh anggota keluarganya untuk melakukan aktifitas ekonomi agar keadaan ekonomi keluarganya tetap bertahan dan seimbang, dan yang terakhir adalah strategi dengan cara migrasi, baik mobilisasi harian maupun migrasi kontemporer dimana mereka hanya bermigrasi sementara hanya untuk bekerja saja.

Pemanfaatan hubungan sosial dengan membentuk relasi-relasi dari suatu komunitas dirasa mampu membantu penambang untuk berbagai kepentingan dan kebutuhan. Banyaknya jaringan memudahkan seseorang untuk meminta bantuan ketika sedang dilanda kesulitan atau terjadi krisis karena semakin luas jaringan, maka semakin banyak pula opsi atau 
pilihan yang dapat digunakan untuk meminta bantuan.

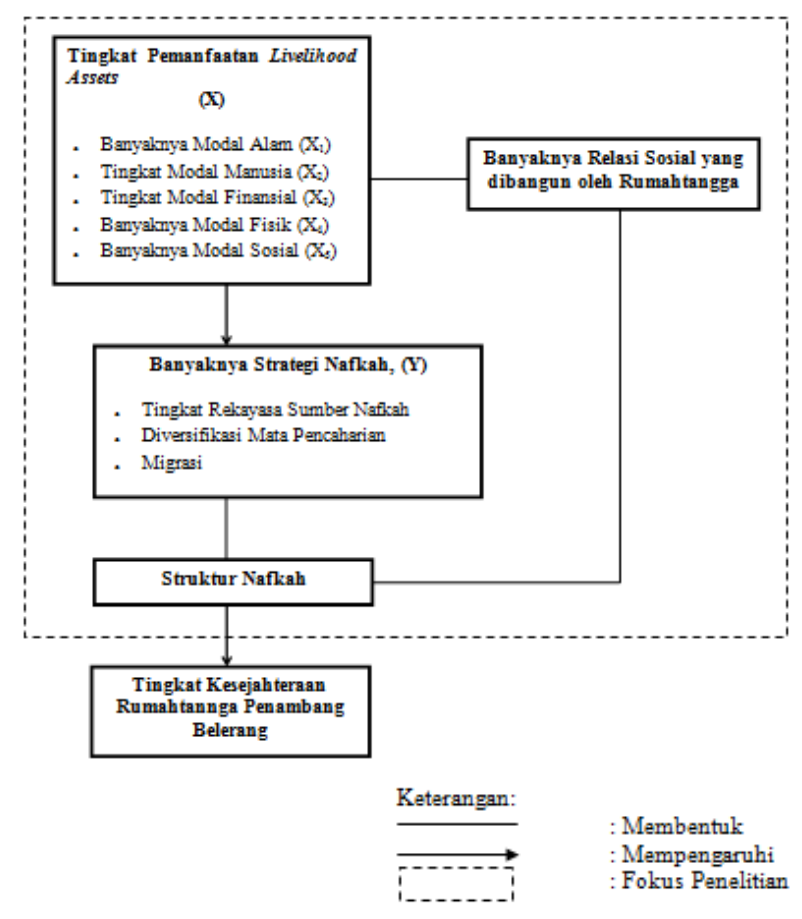

\section{METODE PENELITIAN}

Penelitian ini merupakan penelitian yang menggunakan metode kuantitatif yang didukung dengan data kualitatif. Metode kuantitatif dilakukan dengan pendekatan survei menggunakan kuesioner sebagai instrumen utama penelitian. Sementara itu, data kualitatif merupakan data hasil dari wawancara mendalam, observasi lapang, dan penelusuran dokumen. Penelitian ini akan dilaksanakan di Desa Tamansari, Kecamatan Licin, Kabupaten Banyuwangi, Jawa Timur. Lokasi tersebut dipilih secara purposive karena kajian pada lokasi penelitian ini mampu menjawab hipotesis dan Desa Tamansari merupakan satu desa dengan mayoritas penduduknya bermata pencaharian sebagai penambang belerang Penelitian ini dilaksanakan pada bulan April 2017.

Responden dalam penelitian ini dilakukan dengan mengambil sampel dari suatu populasi dan menggunakan kuesioner sebagai alat pengumpulan data pokok dan diberikan kepada responden yakni rumah tangga petani tebu yang dipilih menggunakan teknik simple random sampling. Pemilihan informan jumlahnya tidak ditentukan dan dilakukan secara sengaja (purposive). Orang-orang yang dijadikan informan dalam penelitian ini meliputi tokoh masyarakat, aparat desa, dan penambang belerang.
Jenis data yang digunakan dalam penelitian ini adalah data primer dan data sekunder. Sumber data primer diperoleh melalui pengamatan langsung pada lokasi penelitian survei dan wawancara dengan responden dan informan. Pertanyaan dalam kuesioner dan panduan wawancara mendalam merupakan data dan informasi yang dibutuhkan dalam menjawab perumusan masalah dalam penelitian ini. Sumber data sekunder diperoleh melalui data monografi desa, dokumen desa, dan kajian pustaka dari literatur yang mendukung penelitian. Data yang telah terkumpul dianalisis dengan melakukan reduksi data, yakni pemilihan, pemusatan perhatian, serta penyederhanaan terhadap data sehingga menjawab tujuan penelitian. Data yang diperoleh melalui kuesioner diolah dengan menggunakan Microsoft Excel 2007 sebelum dimasukan ke perangkat lunak SPSS 23 for Windows untuk mempermudah pengolahan data. Uji statistik yang digunakan yakni uji regresi untuk melihat pengaruh antara variabel yang diuji.

Tingkat kesalahan yang digunakan dalam penelitian ini adalah sebesar 20 persen atau dengan taraf nyata a 0.2 dengan tingkat kepercayaan sebesar 80 persen. Data kualitatif dari wawancara mendalam dan observasi disajikan secara deskriptif untuk mendukung dan memperkuat analisis kuantitatif. Gabungan dari data kuantitatif dan kualitatif diolah dan dianalisis untuk disajikan dalam bentuk teks naratif, matriks, bagan dan gambar. Tahap terakhir yaitu menarik kesimpulan sesuai dengan rumusan masalah dan tujuan penelitian.

\section{HASIL DAN PEMBAHASAN}

\section{Karakter Sosio - Eko - Budaya Masyarakat Penambang Belerang di Kawah Ijen}

\section{Interaksi Sosial}

Interaksi sosial yang terjadi dalam masyarakat yang tinggal di Desa Tamansari, Kecamatan Licin, Kabupaten Banyuwangi lebih mengutamakan kerjasama dan gotong royong dalam proses interaksi sosial mereka. Contohnya dalam hal pembangunan fasilitas desa, masyarakat Dusun Kebundadap, Desa Tamansari yang terdiri dari bapak-bapak dan para pemuda desa secara sukarela bergotong royong membuat pipa-pipa air dari bambu dan kayu yang digunakan untuk memenuhi fasilitas air bersih di dusun mereka. Pipa-pipa tersebut mereka sambungkan mulai dari sumber mata air hutan pinus 
yang berjarak sekitar $3 \mathrm{~km}$ dari Dusun Kebundadap hingga sampai ke kamar mandi umum dan beberapa rumah-rumah warga

\section{Kondisi Sosio-Budaya}

Keunikan dari penambangan belerang di Gunung Ijen adalah adanya sebuah tradisi yang tidak pernah ditinggalkan oleh masyarakat penambang belerang dari sejak awal penambangan hingga saat ini yang dinamakan "Upacara Suroan". Tradisi yang sudah menjadi sebuah keharusan agar tetap selalu dilaksanakan setiap waktu tertentu. Kegiatan ritual ini dilaksanakan oleh masyarakat Desa Tamansari khususnya penambang belerang setiap bulan suro.

Ritual yang dilakukan ini memiliki makna religi yang sangat tinggi. Acara ritual ini biasanya dilakukan dengan memberikan sesaji serba tujuh rupa atau macam setiap menginjak bulan suro, yakni dengan sesaji jenang tujuh rupa atau warna yang biasa dikenal dengan "jenang pitu", kemudian kembang tujuh macam serta jajanan atau kue-kue pasar yang juga tujuh macam. Pemberian sesaji serba tujuh ini merupakan sebuah penhayatan kepercayaan masyarakat penambang bahwa alam yang diciptakan serba tujuh, yakni langit dan bumi yang berlapis tujuh, kemudian surga dan neraka yang terdiri dari tujuh tingkatan, serta jumlah hari yang juga tujuh hari. Adanya sebuah persepsi para penambang bahwa dengan memberikan sesembahan serba tujuh maka tujuh penjaga langit dan tujuh penjaga bumi akan selalu memberikan keselamatan dan berkah dengan tetap menjaga sumber belerang dan Gunung Ijen tetap member sebuah manfaat yang berguna bagi mereka.

\section{Etika Ekonomi}

Harga bahan kebutuhan pokok yang terus meningkat setiap tahunnya membuat sebagian masyarakat di Indonesia melakukan segala cara untuk tetap dapat memenuhi kebutuhan tersebut. Ketidakmampuan sebagian masyarakat dalam memenuhi keinginannya seringkali membuat mereka menjadi frustasi. Masyarakat yang tinggal di Dusun Kebundadap, Desa Tamansari memiliki etika ekonomi yang pasrah terhadap alam khususnya para penambang belerang. Para penambang tetap melakukan pekerjaan menambang mereka meskipun pendapatan yang mereka dapatkan dari hasil menambang dirasa tidak setimpal dengan apa yang sudah mereka kerjakan dengan segala resiko yang mereka hadapi, yaitu sebesar Rp 1.000 per kilogram belerang. Meskipun berada dalam kondisi yang kekurangan dan kondisi pekerjaan yang jauh berbeda dengan apa yang dilakukan oleh masyarakat perkotaan, mereka tetap merasa bersyukur atas apa yang telah mereka dapatkan.

\section{Peran Perempuan dalam Rumahtangga Penambang Belerang}

Perempuan dalam rumahtangga penambang belerang di Dusun Kebundadap, Desa Tamansari cenderung dilokalisir pada pekerjaan domestik. Peran mereka dalam rumahtangga adalah untuk merawat anak, memberi makan ternak dan mengurus pekerjaan rumahtangga seperti menyapu, memasak, mengepel dan mencuci. Pekerjaan di ruang publik cenderung bahkan hanya dilakukan oleh kaum laki-laki. Hal ini dikarenakan masyarakat di pedesaan khususnya di Dusun Kebundadap, Desa Tamansari masih memegang teguh keyakinan mereka bahwa kaum laki-laki lah yang selayaknya melakukan pekerjaan di ruang publik dan kaum perempuan lah yang selayaknya bekerja di sekor domestik. Perempuan di Dusun Kebundadap, Desa Tamansari akan memberanikan diri untuk bekerja di ruang publik apabila sudah ditinggal suaminya atau sudah tidak ada lagi laki-laki yang dianggap mampu untuk mencari nafkah dalam rumahtangga.

\section{Kondisi Demografi}

Para penambang belerang di Kawah Ijen dalam hal usia didominasi oleh para penambang dengan usia produktif, yaitu 30 hingga 50 tahun. Kondisi fisk, kesehatan dan tenaga merupakan faktor utama yang menentukan usia kerja para penambang belerang. Pekerjaan menambang belerang merupakan pekerjaan yang penuh dengan resiko, maka dari itu jarang ditemukan penambang belerang yang berusia kurang dari 30 tahun dan lebih dari 55 tahun. Selanjutnya dalam segi kependudukan, para penambang belerang di Dusun Kebundadap, Desa Tamansari melakukan migrasi secara sirkuler atau migrasi yang dilakukan dalam jangka waktu yang singkat. Para penambang biasanya bermigrasi ke Banyuwangi Kota dan beberapa lokasi di Pulau Bali dengan mayoritas pekerjaan yang mereka lakukan 
adalah bekerja sebagai buruh bangunan di lokasilokasi tersebut.

\section{Interaksi Ekologi}

Interaksi ekologi dapat diartikan dengan bagaimana manusia beradaptasi dengan lingkungan untuk memenuhi kebutuhannya. Para penambang melakukan aktifitas penambangan sejak pukul 23.00 WIB hingga pukul 11.00 WIB setiap harinya. Penambangan hanya dilakukan pada waktu-waktu tersebut karena intensitas gas belerang yang beracun dan dapat berbahaya bagi kesehatan masih tergolong rendah. Gas beracun tersebut akan memasuki intensitas yang tinggi di atas pukul 13.00 WIB. Para penambang belerang pun telah memiliki kearifan lokal dimana sebelum intensitas gas belerang tinggi, para penambang secara otomatis akan meninggalkan kawah ijen untuk menghindari resiko-resiko kesehatan dan bahaya lainnya yang mungkin dapat terjadi.

\section{Komunikasi}

Jenis komunikasi yang dibangun oleh masyarakat di Dusun Kebundadap, Desa Tamansari adalah jenis komunikasi ineterpersonal atau komunikasi antar pribadi. Komunikasi interpersonal dilakukan secara tatap muka yang memungkinkan respons verbal maupun non verbal terjadi secara langsung. Rumahtangga penambang belerang menggunakan jenis komunikasi ini karena mereka hidup dan berkumpul dalam suatu lingkup lingkungan yang sama dan dalam kelompok-kelompok kecil. Teknologi komunikasi seperti handphone memang sudah masuk kedalam lingkungan mereka, namun tidak semua rumahtangga memilikinya dan teknologi ini hanya digunakan untuk sesekali menghubungi kerabat-kerabat yang bertempat tinggal di luar wilayah Desa Tamansari.

\section{Teknologi Sederhana}

Penambang Belerang di Kawah Ijen masih tergolong tradisional karena penambangan belerang masih dilakukan dengan menggunakan linggis. Linggis digunakan oleh para penambang belerang untuk mencongkel dan memecah bongkahan-bongkahan belerang yang terdapat di sumber belerang. Bongkahan-bongkahan belerang tersebut mereka angkut dengan menggunakan keranjang yang terbuat dari bambu. Para penambang mayoritas membuat sendiri keranjang mereka dengan memanfaatkan bambu yang tumbuh di sekitar tempat tinggal mereka. Namun terdapat beberapa penambang yang lebih memilih untuk membeli keranjang jadi yang dijual oleh penambang lainnya untuk lebih menghemat waktu dengan harga Rp 50.000 untuk satu set keranjang. Keranjang-keranjang tersebut biasanya akan diganti oleh para penambang setiap delapan bulan sekali atau pada saat keranjang tersebut sudah mulai rusak.

\section{Organisasi Produksi Penambang Belerang}

\section{Penambang Belerang}

Kegiatan penambangan belerang di Kawah Ijen merupakan hasil dari proses adaptasi ekologi antara masyarakat dengan alam. Para penambang belerang tertarik untuk bekerja sebagai penambang belerang karena tidak dituntut keahlian tertentu untuk melakukan pekerjaan ini sehingga mereka dengan mudah dapat bekerja di sektor ini. Disamping pekerjaannya sebagai penambang belerang, mereka juga mempunyai pekerjaan sampingan seperti tukang kayu, porter, penyedia jasa sewa masker, tour guide, buruh bangunan, peternak dan pedagang. Pekerjaan sampingan ini mereka lakukan untuk mengisi waktu luang yang mereka miliki saat mereka tidak melakukan penambangan belerang.

Aktivitas yang dilakukan oleh para penambang dilakukan dengan berjalan sejauh 1,5 km menuruni bawah tepian danau Kawah Ijen yang mana pada bagian tersebut terdapat wilayah berbatu berwarna kuning dan mengeluarkan asap dimana itu merupakan sumber belerang yang ditambang oleh para penambang. Penambang belerang biasanya berangkat dari rumah pada malam hari yaitu sekitar pukul 23.00 WIB dan sampai tempat penginapan yang terletak di Paltuding kira-kira pukul 24.00 WIB. Biasanya para penambang belerang bercengkrama hingga pukul 01.00 WIB. Setelah menyiapkan segala sesuatunya mereka berangkat menuju Pondok Bunder pukul 02.00 WIB dengan waktu tempuh sekitar 2 jam perjalanan. Selanjutnya para penambang belerang melanjutkan perjalannya menuju Kawah Ijen dengan waktu tempuh kurang lebih satu jam perjalanan dengan istirahat, setelah itu penambang melakukan pengambilan belerang sebanyak dua keranjang sesuai dengan kemampuan masing-masing penambang. Selanjutnya belerang 
diangkut dari kawah menuju puncak dengan cara dipikul lalu dilanjutkan ke Pondok Bunder dengan mengguknakan trolly untuk ditimbang sesuai dengan nomor kupon yang diberikan sebelumnya. Setelah itu, belerang dibawa ke penampungan yang berada di Desa Tamansari untuk di olah sebelum akhirnya di pasarkan ke seluruh Indonesia. Kegiatan ini terus mereka lakukan setiap hari kecuali hari Jum'at. Penambang meliburkan diri dari kegiatan menambang pada hari jum'at karena adanya waktu Shalat Jum'at.

\section{Proses Penambangan dan Pengolahan Belerang}

Kegiatan penambangan ini hanya berlangsung tidak lebih dari jam 11 siang, sebab sesudahnya akan muncul asap tebal yang mengandung solfatara yang berbahaya bagi kesehatan. Kepulan asap yang tampak dari atas bukit merupakan pertanda telah dimulainya aktivitas penambangan seiring dengan terbitnya matahari pagi. Kepulan asap dan bau belerang yang menyengat adalah hal biasa bagi para penambang belerang.

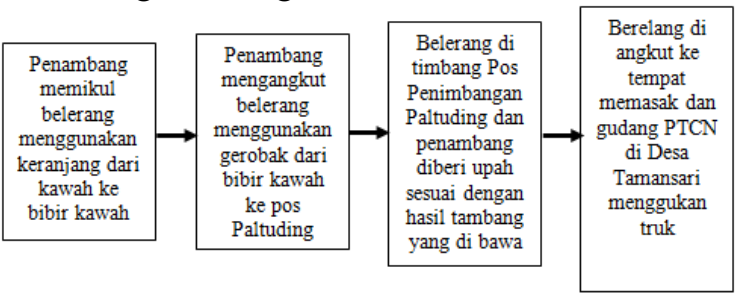

Gambar 1 Proses Pengangkutan Belerang di Desa Tamansari, Kecamatan Licin tahun 2017

Perusahaan tempat para penambang bekerja memberikan asuransi kecelakaan kerja namun dengan syarat asuransi ini berlaku semasa jam kerja saja yaitu mulai pukul $05.00 \mathrm{WIB}$ sampai pukul 14.00 WIB. Diluar jam itu resiko ditanggung oleh penambang sendiri. Berikut sekema proses pengangkutan belerang.

Para penambang pada umumnya menambang setiap hari kecuali hari Jum'at atau Kamis malam karena waktu yang kurang memungkinkan akibat adanya ibadah Sholat Jum'at. Pengangkutan belerang oleh truk dilakukan mulai pukul 11.00 siang hingga pukul 17.00 sore setiap harinya. Cara pengolahan atau pemurnian yang dilakukan oleh PTCN adalah dengan memisahkan kotoran dan bahan lain yang ikut tercampur bersama endapan belerang murni dengan kadar 99,8\%. Berikut ini merupakan skema pengolahan atau pemurnian belerang.

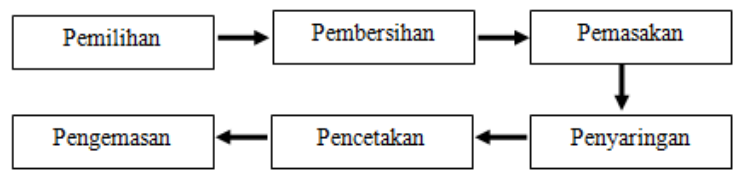

Gambar 2 Proses Pengolahan Belerang di Desa Tamansari, Kecamatan Licin tahun 2017

Pemilihan dilakukan dengan cara menuai belerang mentah yang diambil dari sulfatara yang tidak terkontaminasi bahan lain, sehingga didapatkan bongkahan-bongkahan belerang murni. Selanjutnya pembersihan belerang mentah yang berasal dari sulfatara yang terontaminasi bahan lain hanya permukaannya saja yang dibersihkan dengan menggunakan pisau bendo sehingga didapatkan bongkahan-bongkahan belerang murni. Belerang mentah yang telah dimurnikan dengan kedua cara diatas dikumpulkan untuk dimasak dengan menggukanan wajan besar pada suhu tertentu dengan bantuan kayu bakar sehingga kembali mencair. Belerang yang mencair dan yang tercampur kotoran kemudian disaring dengan kawat monel dan kain blacu, hasil saringan berupa cairan belerang kemudian disalurkan kedalam drum-drum berukuran sedang untuk kemudian di cetak sesuai dengan kebutuhan pada konsumen.

\section{Transportasi dan Perlengkapan Kerja Penambang}

Pengangkutan belerang dari dapur sulfatara masih menggunakan tenaga manusia. Para penambang harus berjalan mendorong gerobak berisikan puluhan kilo belerang sejauh kurang lebih empat kilometer menuruni gunung ijen hingga sampai di pos Paltuding untuk menimbang hasil tambang belerang dan selanjutnya diberikan upah atas hasil menambang mereka sesuai dengan jumlah belerang yang mereka bawa. Pengangkutan belerang dari pos Paltuding hingga ke PTCN yang terletak di Desa Tamansari dilakukan dengan menggukana truk.

Berbagai peralatan yang digunakan oleh para penambang untuk mengambil belerang di Kawah Ijen ternyata masih sederhana dan beresiko tinggi 
terhadap keselamatan kerja para penambang. Mereka menggunakan keranjang besar yang terbuat dari anyaman kayu dengan bantuan alat sederhana yaitu kain dan terkadang ada penambang yang memakai sarung tangan sederhana untuk mengambil bongkahan-bongkahan belerang. Dasar Kawah Ijen diselimuti oleh kepulan asap belerang yang tebal dengan bau khas menyengat hidung namun puluhan penambang tampak tenang mengambil belerang di lokasi tersebut meski tanpa dilengkapi oleh masker oksigen. Mereka hanya menggunakan lilitan kain sarung basah untuk menutupi sebagian wajahnya dari paparan asap belerang. Kain sarung yang basah tersebut menurut mereka setidaknya mampu menetralisir bau belerang agar tidak terlalu berefek buruk bagi pernafasan mereka. Cara ini dilakukan hampir oleh seluruh penambang belerang yang menambang di Kawah Ijen.

\section{Bargaining Power}

Bargaining Power merupakan kedudukan seseorang terhadap berbagai relasi-relasi sosial yang dimilikinya. PTCN yang berpusat di Surabaya ini merupakan satu-satunya perusahaan yang mengelola penambangan belerang yang ada di Gunung Ijen dan telah mendapatkan ijin resmi dari pemerintah daerah Banyuwangi sehingga semua hasil tambang belerang harus ditampung oleh PTCN. Para penambang tidak berani menjual belerangnya kepada pihak lain karena ada mandor yang mengawasi pekerjaan mereka dan menimbang serta mencatat berapa banyak belerang yang diangkut oleh para penambang. Dengan demikian produksi belerang PTCN semakin meingkat karena para penambang belerang PTCN hanya menjual hasil tambangnya ke PTCN sehingga bargaining power yang dimiliki oleh para penambang belerang terhadap pihak PTCN tergolong lemah.

\section{Struktur Nafkah Penambang Belerang}

Struktur Nafkah rumahtangga penambang belerang dilihat berdasarkan berbagai sumber pendapatan yang berasal dari sektor non-pertanian (menambang dan bukan menambang). Rumahtangga penambang belerang dikategorikan menjadi tiga lapisan menurut pendapatannya. Pengkategorian lapisan rumahtangga ini dihitung dengan mengolah datadata yang diperoleh melalui kuesioner dengan rumus jika $<\mathrm{x}-1 / 2$ sd maka termasuk pada lapisan bawah, jika $x-1 / 2$ sd $\leq x \leq+1 / 2$ sd maka termasuk pada lapisan menengah, dan jika $>x+1 / 2$ sd maka termasuk pada lapisan atas. Rumahtangga penambang pada lapisan bawah memiliki pendapatan $<$ Rp 40.900 .000 per tahun, lapisan sedang memiliki pendapatan berkisar $\mathrm{Rp}$ 40.900.000 sampai Rp 85.600.000 per tahun, sedangkan untuk lapisan tinggi memiliki pendapatan $>\operatorname{Rp} 85.600 .000$.

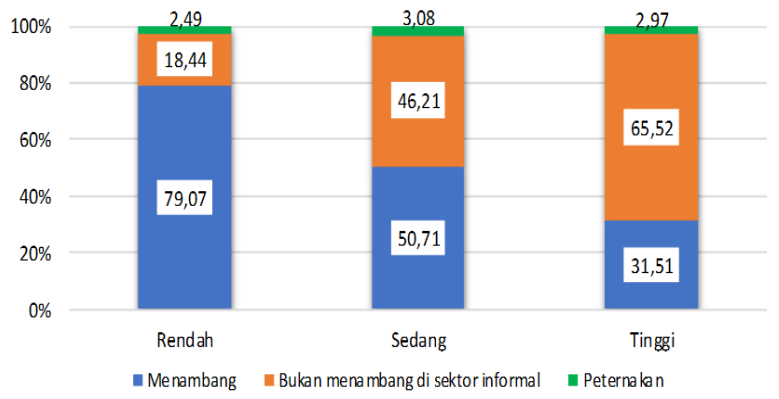

Gambar 3 Struktur pendapatan rumahtangga penambang belerang per tahun berdasarkan lapisan pendapatan (dalam persentase) di Desa Tamansari, Kecamatan Licin tahun 2017

Berdasarkan gambar tersebut maka dapat diterangkan bahwa:

1. Semakin rendah lapisan rumahtangga maka semakin penting kontribusi pendapatan yang diperoleh dari aktivitas menambang bagi sistem penghidupan.

2. Semakin tinggi lapisan rumahtangga maka semakin kecil kontribusi pendapatan yang berasal dari aktivitas menambang. Sebaliknya, semakin tinggi lapisan rumahtangga maka kontribusi pendapatan yang berasal dari aktivitas bukan menambang di sektor informal semakin besar.

3. Meskipun semakin tinggi lapisan rumahtangga maka semakin rendah kontribusi pendapatan yang berasal dari aktivitas menambang. Namun, aktivitas menambang masih menjadi aktivitas nafkah penting bagi rumahtangga.

\section{Saving Capacity Rumahtangga Penambang Belerang}

Saving capacity atau kapasitas menabung rumahtangga dapat diartikan sebagai selisih antara 
pendapatan dengan pengeluaran suatu rumahtangga. Pedapatan rumahtangga ini dibangun oleh dua sumber aktivitas, yaitu aktivitas menambang dan bukan menambang.

Berdasarkan hasil penelitian dapat disimpulkan bahwa pada semua lapisan pendapatan rumahtangga penambang belerang bisa menabung walaupun pada lapisan lapisan bawah memiliki kemampuan menabung dengan jumlah yang lebih sedikit sedikit.

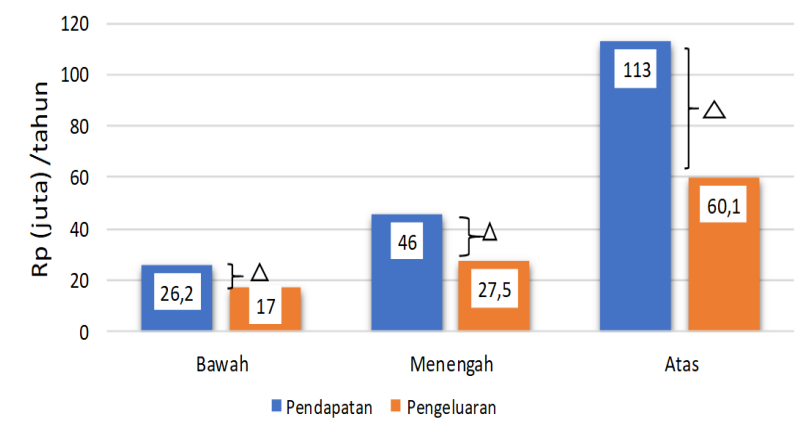

Keterangan: A Merupakan bagian yang berpotensi untuk ditabung

Gambar 4 Perbandingan antara rata-rata pendapatan dengan pengeluran rumahtangga penambang belerang per satu tahun dilihat berdasarkan lapisan pendapatan di Desa Tamansari, Kecamatan Licin tahun 2017

Kapasitas menabung yang dimiliki oleh rumahtangga penambang belerang, baik pada lapisan bawah, menengah, maupun atas, diinvestasikan kedalam bentuk berupa barang, hewan ternak dan juga investasi dengan menyimpan uang tersebut di dalam rumah. Investasi barang yang dilakukan oleh rumahtangga dapat berupa investasi barang-barang elektornik, motor dan perhiasan. Investasi dengan cara ini dapat digunakan dengan cara menjual ataupun menggadaikan barang-barang tersebut jika sewaktu-waktu membutuhkan biaya. Sementara investasi dengan cara menyimpan uang di dalam rumah, cenderung dilakukan dengan nominal uang yang tidak terlalu besar.

\section{Strategi Nafkah Rumahtangga Penambang Belerang}

1. Strategi Bertahan Hidup dengan Mengadopsi Berbagai Aktivitas Ekonomi oleh Rumahtangga Penambang Belerang
Sumber pendapatan yang diperoleh rumahtangga penambang belerang di Desa Tamansari didominasi oleh sumber pendapatan di sektor informal. Kurangnya keterampilan dan pengetahuan para penambang menyebabkan sulitnya bagi rumahtangga ini untuk menembus sektor formal. Akibatnya sektor informal dipilih sebagai jawaban atas ketidakmampuan mereka menembus sektor formal. Sektor informal dianggap memiliki peranan yang cukup besar dalam menampung kelebihan angkatan kerja di sektor formal.

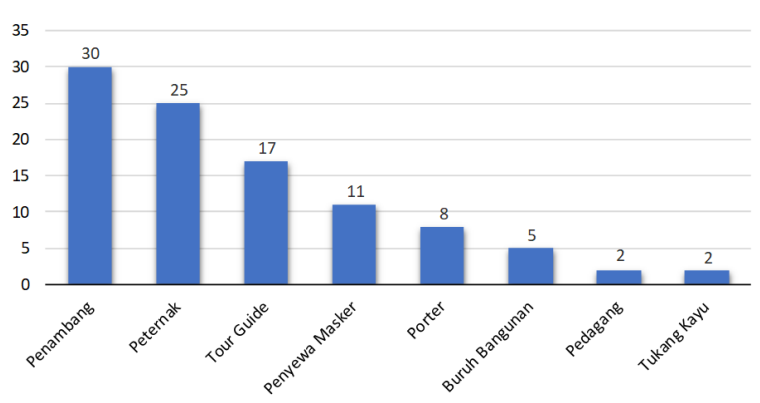

Gambar 5 Jenis aktivitas yang ditekuni oleh rumahtangga penambang belerang untuk bertahan hidup di Desa Tamansari, Kecamatan Licin tahun 2017

\section{Strategi Bertahan Hidup dengan Rekayasa Spasial}

Migrasi merupakan suatu fenomena yang terbentuk akibat pembangunan ekonomi yang tidak merata antara desa dan kota. Tidak adanya pekerjaan tetap serta rendahnya pendapatan yang diperoleh ketika berada di desa mendorong rumahtangga untuk berpindah ke daerah perkotaan dengan harapan untuk meningkatkan kesejahteraan rumahtangga. Jenis migrasi yang dilakukan oleh rumahtangga penambang di Desa Tamansari adalah migrasi sirkuler. Rumahtangga penambang ini bermigrasi dengan menggunakan jaringan kekerabatan dan pertemanan yang mereka miliki. Mayoritas pelaku migrasi di Desa Tamansari melakukan migrasi sirkuler ke daerah Bali dan bekerja sebagai buruh bangunan atau buruh pabrik.

\section{Mempekerjakan Anggota Keluarga}

Strategi nafkah mempekerjakan anggota rumahtangga bukan merupakan salah satu strategi nafkah pilihan utama yang dilakukan oleh rumahtangga penambang belerang di Desa 
Tamansari. Hal ini dikarenakan sebanyak 4 rumahtangga mempekerjakan satu anggota keluarganya selain kepala keluarga. Sementara itu ada 26 rumahtangga yang hanya mengandalkan dirinya sendiri sebagai pencari nafkah rumahtangga.

Strategi nafkah dengan mempekerjakan anggota keluarga ini mampu menambah sumbangan pendapatan rumahtangga. Selain itu, alokasi waktu dan tenaga yang dilakukan oleh anggota rumahtangga lainnya mampu meringankan beban kepala rumahtangga dalam memenuhi kebutuhan kehidupan keluarganya. Lapisan rumahtangga dengan pendapatan rendah melakukan strategi ini karena ketidakmampuan kepala keluarga dalam memenuhi kebutuhan keluarganya khususnya untuk kebutuhan primer rumahtangga. Sementara pada rumahtangga dengan pendapatan pada golongan sedang dan tinggi, strategi ini dilakukan untuk mencukupi kebutuhan primer dan juga sekunder rumahtangga.

\section{Berhutang}

Strategi berhutang dipengaruhi oleh modal sosial terutama jaringan sosial yang dibangun oleh rumahtangga penambang belerang. Modal sosial mempengaruhi strategi ini dalam hal kepercayaan (trust) yang dibangun. Semakin kuat kepercayaan yang dibangun oleh rumahtangga dengan rumahtangga lainnya maka akan semakin mudah akses rumahtangga untuk mendapatkan pinjaman berupa uang. Rumahtangga penambang belerang di Desa Tamansari dalam melakukan strategi ini dapat dikategorikan menjadi tiga berdasarkan kepada siapa rumahtangga melakukan strategi ini, pertama rumahtangga yang berhutang pada perbankan, kedua rumahtangga yang berhutang pada tetangga atau kerabat, dan ketiga rumahtangga yang berhutang pada warung.

Strategi nafkah berhutang kepada pihak perbankan dilakukan karena mereka membeli motor dengan cara kredit atau mencicil dimana pembayarannya dilakukan dengan membayar tagihan tersebut kepada pihak perbankan setiap sebulan sekali selama lebih dari satu tahun. Strategi nafkah berhutang kepada saudara dan tetangga atau teman dilakukan oleh rumahtangga penambang belerang dengan pendapatan pada lapisan rendah dan sedang. Hal ini dikarenakan ketidakmampuan secara finansial rumahtangga penambang belerang pada lapisan rendah dan sedang untuk memenuhi kebutuhan mereka sehari-hari.

\section{Mengganti Jenis Makanan}

Strategi nafkah dengan mengganti jenis makanan dilakukan oleh rumahtangga penambang belerang dengan pendapatan pada lapisan rendah. Strategi nafkah ini merupakan bagian dari proses penekanan pengeluaran saat rumahtangga penambang belerang berada dalam kondisi krisis. Strategi ini dilakukan dengan tujuan untuk tetap mempertahankan keberadaan rumahtangga pada saat sulit/krisis. Rumahtangga penambang belerang mampu menekan biaya pengeluaran sehingga mampu mengurangi beban ketika krisis terjadi dengan menerapkan strategi ini. Meskipun demikian, strategi nafkah ini merupakan pilihan yang tidak menyenangkan bagi rumahtangga penambang belerang, karena kebutuhan akan makanan merupakan kebutuhan dasar yang dipengaruhi oleh selera bagi tiap-tiap individunya

\section{Relasi Sosial Rumahtangga Penambang Belerang}

\section{Relasi Rumahtangga Penambang Belerang dengan PTCN}

Hubungan yang terjalin antara penambang belerang dengan PTCN merupakan hubungan yang bersifat saling membutuhkan antar satu sama lain. Para penambang memerlukan pihak perusahaan untuk mendapatkan pekerjaan dan memperoleh uang guna mencukupi kebutuhan hidup sehari-hari, sedangkan pihak perusahaan membutuhkan para penambang belerang untuk membantu perusahaan dalam memenuhi kebutuhan belerang yang merupakan produk jual utama dari perusahaan ini.

Relasi yang terjalin antara rumahtangga penambang belerang dengan PTCN merupakan relasi sosial yang bersifat assosiatif dimana terjalin kerjasama antara rumahtangga penambang dengan pihak perusahaan yang bersifat positif dan saling menguntungkan. Pihak perusahaan rutin memberikan sembako, pakaian layak pakai dan sejumlah uang kepada para penambang yang terdaftar di PTCN setiap menjelang Hari Raya Idul Fitri. 
Tabel 1 Relasi sosial antara rumahtangga penambang belerang dengan PTCN di Desa Tamansari, Kecamatan Licin tahun 2017

\begin{tabular}{|c|c|c|}
\hline Aktor & $\begin{array}{c}\text { Rumahtangga Penambang } \\
\text { Belerang }\end{array}$ & PTCN \\
\hline $\begin{array}{l}\text { Rumahtangga } \\
\text { Penambang Belerang }\end{array}$ & \begin{tabular}{lr}
\multicolumn{3}{l}{ Hubungan antara } & sesama \\
rumahtangga penambang \\
belerang di Desa Tamansari \\
tergolong setara & karena \\
pada dasamya & mereka \\
saling bekerjasama dan & dang \\
saling melengkapi dalam \\
kehidupan & mereka \\
bermasyarakat. & \\
Rumahtangga akan saling \\
membantu satu sama lain \\
apabila ada rumahtangga \\
yang sedang berada dalam \\
kondisi kesulitan.
\end{tabular} & $\begin{array}{lr}\text { Pihak } & \text { perusahaan } \\
\text { mendominasi hubungan yang } \\
\text { terjalin yang dengan } \\
\text { rumahtangga penambang } \\
\text { belerang. Rumahtangga } \\
\text { cenderung mengikuti segala } \\
\text { peraturan dan kebijakan yang } \\
\text { dikeluarkan oleh pihak } \\
\text { perusahaan. }\end{array}$ \\
\hline PTCN & - & - \\
\hline
\end{tabular}

\section{Relasi Rumahtangga Penambang Belerang dengan Bank}

Strategi nafkah dengan cara berhutang berkaitan dengan modal finansial yang dimiliki oleh rumahtangga penambang belerang. Selain modal finansial, strategi berhutang dipengaruhi oleh modal sosial terutama jaringan sosial yang dibangun oleh rumahtangga penambang belerang. Modal sosial mempengaruhi strategi ini dalam hal kepercayaan (trust) yang dibangun. Semakin kuat kepercayaan yang dibangun oleh rumahtangga dengan rumahtangga lainnya maka akan semakin mudah akses rumahtangga untuk mendapatkan pinjaman berupa uang.

Tabel 2 Relasi sosial antara rumahtangga penambang belerang dengan pihak perbankan di Desa Tamansari, Kecamatan Licin tahun 2017

\begin{tabular}{|c|c|c|}
\hline Aktor & $\begin{array}{c}\text { Rumahtangga Penambang } \\
\text { Belerang }\end{array}$ & Bank \\
\hline $\begin{array}{l}\text { Rumahtangga } \\
\text { Penambang Belerang }\end{array}$ & $\begin{array}{l}\text { Hubungan antara sesama } \\
\text { rumahtangga penambang } \\
\text { belerang di Desa Tamansari } \\
\text { tergolong setara karena } \\
\text { pada dasamya mereka } \\
\text { saling bekerjasama dan } \\
\text { saling melengkapi dalam } \\
\text { kehidupan mereka } \\
\text { bermasyarakat. } \\
\text { Rumahtangga akan saling } \\
\text { membantu satu sama lain } \\
\text { apabila ada rumahtangga } \\
\text { yang sedang berada dalam } \\
\text { kondisi kesulitan. } \\
\end{array}$ & $\begin{array}{l}\text { Pihak perusahaan } \\
\text { mendominasi hubungan yang } \\
\text { terjalin yang dengan } \\
\text { rumahtangga penambang } \\
\text { belerang. Hubungan antara } \\
\text { rumahtangga dengan pihak } \\
\text { perbankan terjalin karena } \\
\text { rumahtangga melakukan } \\
\text { sistem kredit untuk motor } \\
\text { dengan pihak perbankan. } \\
\text { Rumahtangga pun cenderung } \\
\text { mengikuti peraturan dan } \\
\text { kebijakan terkait sistem } \\
\text { pembayaran kredit berlaku. }\end{array}$ \\
\hline Bank & - & - \\
\hline
\end{tabular}

Relasi dengan pihak perbankan mayoritas dimiliki oleh seluruh lapisan rumahtangga penambang. Berdasarkan hasil penelitian, diketahui terdapat sebanyak 29 dari 30 rumahtangga yang mencicil kredit motor mereka kepada pihak perbankan lebih dari 5 kali dalam setahun.

\section{Relasi Rumahtangga Penambang Belerang dengan Travel Agent}

Strategi nafkah pemanfaatan jaringan sosial sebagai landasan nafkah utama dalam menjalankan kegiatan nafkah dilakukan dengan cara membangun jaringan sosial berupa jaringan kemitraan bisnis. Jaringan kemitraan bisnis tersebut dilakukan para penambang untuk membangun usaha penyediaan jasa tour guide. Jaringan sosial tour guide ini dibangun antara pihak travel dengan penambang belerang yang menjadi penyedia jasa tour guide.

Travel agent ini umumnya membawakan turis lokal maupun mancanegara yang menyewa jasa travel mereka untuk di guide atau di dampingi oleh para penambang yang bekerja sebagai tour guide saat berunjung ke Gunung Ijen. Para penambang ini dipilih untuk mendampingi turis-turis tersebut oleh para pemilik travel agent dikarenakan pengetahuannya mengenai medan yang akan dilalui serta pengetahuannya mengenai kondisi Gunung Ijen yang dinilai sangat baik oleh para pemilik travel agent tersebut.

Tabel 3 Relasi sosial antara rumahtangga penambang belerang dengan travel agent di Desa Tamansari, Kecamatan Licin tahun 2017

\begin{tabular}{|c|c|c|}
\hline Aktor & $\begin{array}{l}\text { Rumahtangga Penambang } \\
\text { Belerang }\end{array}$ & Tetangga dan Warung \\
\hline $\begin{array}{c}\text { Rumahtangga } \\
\text { Penambang Belerang }\end{array}$ & $\begin{array}{l}\text { Hubungan antara sesama } \\
\text { rumahtangga penambang } \\
\text { belerang di Desa Tamansan } \\
\text { tergolong setara karena } \\
\text { pada dasamya mereka } \\
\text { saling bekerjasama dan } \\
\text { saling melengkapi dalam } \\
\text { kehidupan mereka } \\
\text { bermasyarakat. } \\
\text { Rumahtangga akan saling } \\
\text { membantu satu sama lain } \\
\text { apabila ada rumahtangga } \\
\text { yang sedang berada dalam } \\
\text { kondisi kesulitan. }\end{array}$ & $\begin{array}{l}\text { Hubungan yang terjalin antara } \\
\text { rumahtangga penambang } \\
\text { belerang dengan sesama } \\
\text { tetangga mereka dan warung } \\
\text { tergolong setara. Halini dapat } \\
\text { terjadi karena mereka hidup } \\
\text { dalam suatu lingkungan yang } \\
\text { sama. Tingginya kepercayaan } \\
\text { antar pihak membuat para } \\
\text { tetangga danwarungyang ada } \\
\text { di lingkungan sekitar } \\
\text { rumahtangga penanbang tidak } \\
\text { merasa sungkan untuk saling } \\
\text { membantu apabila ada } \\
\text { rumahtangga yang sedang } \\
\text { mengalami kesulitan dengan } \\
\text { bantuan berupa pinjaman uang } \\
\text { atau hutang untuk keperluan } \\
\text { pangan rumahtangga sehar- } \\
\text { hari. }\end{array}$ \\
\hline $\begin{array}{l}\text { Tetangga dan } \\
\text { Warung }\end{array}$ & - & $\begin{array}{l}\text { Hubungan antar sesama } \\
\text { tetangga danwarungyang ada } \\
\text { di lingkungan Dusun } \\
\text { Kebundadap cenderung } \\
\text { setara. Kedua pihak ini } \\
\text { cenderung memiliki relasi } \\
\text { yang baik. Mereka tak } \\
\text { sungkanuntukmeminta saling } \\
\text { memberikan bantuan antar } \\
\text { sesama apabila ada pihakyang } \\
\text { sedangmembutuhkan bartuan }\end{array}$ \\
\hline
\end{tabular}




\section{Relasi Rumahtangga Penambang Belerang dengan Tetangga dan Warung}

Modal sosial khususnya trust (kepercayaan) yang dibangun oleh rumahtangga dengan rumahtangga lainnya menjadi faktor penentu apakah seseorang akan memberikan pinjaman atau tidak. Semakin kuat trust yang dibangun maka akan semakin mudah akses rumahtangga untuk melakukan pinjaman. Rumahtangga penambang belerang akan secara bergantian memberikan pinjaman kepada rumahtangga lainnya ketika membutuhkan untuk menjaga modal sosial ini. Ketidakmampuan rumahtangga penambang belerang untuk memprediksi krisis yang akan terjadi menyebabkan mereka harus melakukan strategi nafkah dengan cara berhutang.

Tabel 4 Relasi sosial antara rumahtangga penambang belerang dengan tetangga dan warung di Desa Tamansari, Kecamatan Licin tahun 2017

\begin{tabular}{|c|c|c|}
\hline Aktor & $\begin{array}{c}\text { Rumahtangga Penambang } \\
\text { Belerang } \\
\end{array}$ & Travel Agent \\
\hline $\begin{array}{l}\text { Rumahtangga } \\
\text { Penambang Belerang }\end{array}$ & $\begin{array}{l}\text { Hubungan antara sesama } \\
\text { rumahtangga penambang } \\
\text { belerang di Desa Tamansari } \\
\text { tergolong setara karena } \\
\text { pada dasarnya mereka } \\
\text { saling bekerjasama dan } \\
\text { saling melengkapi dalam } \\
\text { kehidupan mereka } \\
\text { bermasyarakat. } \\
\text { Rumahtangga akan saling } \\
\text { membantu satu sama lain } \\
\text { apabila ada rumahtangga } \\
\text { yang sedang berada dalam } \\
\text { kondisi kesulitan. }\end{array}$ & $\begin{array}{l}\text { Hubungan yang terjalin antara } \\
\text { rumahtangga dan pihak travel } \\
\text { agent cenderung bersifat } \\
\text { setara. Meskipun pihak travel } \\
\text { agent merupakan pihak yang } \\
\text { penting dalam hubungan ini, } \\
\text { namun pada dasarnya mereks } \\
\text { saling bekerjasama dan saling } \\
\text { membutuhkan antara satu } \\
\text { sama lain. Pihak travel } \\
\text { membutuhkan para } \\
\text { penambang untuk dapat } \\
\text { memandu para pengguna } \\
\text { jasanya pada saat mereks } \\
\text { sedang melakukan pendakian } \\
\text { ke Gunung Ijen karena para } \\
\text { penambangdianggap memiliki } \\
\text { kemampuan dan keahlian } \\
\text { dalam hal ini. Pada sisi lain } \\
\text { rumahtangga pun } \\
\text { membutuhkan pihak travel } \\
\text { agent untuk dapat menjadi } \\
\text { mitra nya dalam melakukan } \\
\text { aktifitas nafkah sebagai tour } \\
\text { guide guna menambah } \\
\text { pemasukan mantuk untul } \\
\text { rumahtangga mereks. }\end{array}$ \\
\hline Travel Agent & - & $\begin{array}{l}\text { Hubungan yang terjalin antar } \\
\text { travel agent cenderung setara. } \\
\text { Para pemilik travel agent ini } \\
\text { saling bekerjasama dalam } \\
\text { mengalokasi para wisatawan } \\
\text { yang ingin berkunjung ke } \\
\text { Gunung Ijen. Namun, tak } \\
\text { jarang juga mereka saling } \\
\text { bersaing dalam mencari } \\
\text { wisatawan } \\
\text { menggunakan jasa mereka. }\end{array}$ \\
\hline
\end{tabular}

Relasi ini dinilai menguntungkan untuk memenuhi kebutuhan yang sifatnya mendesak. Relasi dengan tetangga dan warung dibangun dengan memanfaatkan modal sosial berupa trust (kepercayaan). Pentingnya kepercayaan dalam melakukan strategi berhutang membuat rumahtangga penambang belerang berusaha menjaga kepercayaan ini dengan cara memberikan pinjaman balik atau pun mengembalikan pinjaman sesegera mungkin.

\section{Pemanfaatan Modal Nafkah Rumahtangga Penambang Belerang}

Rumahtangga penambang belerang di Desa Tamansari dikelompokkan menjadi tiga lapisan yaitu lapisan rendah, sedang, dan tinggi. Setiap lapisan rumahtangga penambang belerang memiliki kecenderungan terhadap pemanfaatan modal nafkah yang berbeda-beda. Pembagian lapisan tersebut bertujuan untuk mengetahui sejauh mana pemanfaatan modal nafkah yang dilakukan rumahtangga penambang belerang pada lapisan rendah, lapisan sedang, dan lapisan tinggi di Desa Tamansari.

Modal alam pada rumahtangga penambang belerang mencakup jumlah belerang yang dapat dikumpulkan oleh penambang, luas lahan yang dimiliki serta banyaknya sumberdaya alam yang dapat diakses oleh rumahtangga. Modal alam pada rumahtangga bawah bernilai rendah, pada rumahtangga lapisan menengah bernilai sedang, sedangkan pada rumahtangga lapisan atas bernilai tinggi.

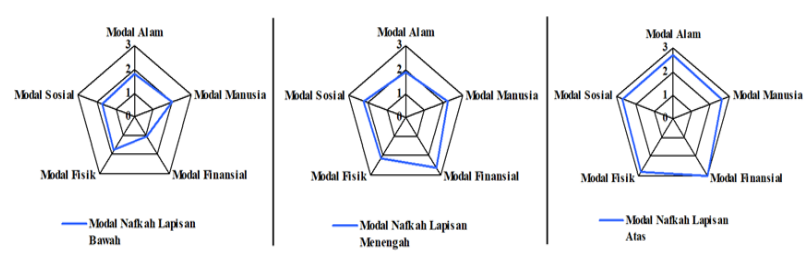

Gambar 6 Pemanfaatan modal nafkah rumahtangga penambang belerang berdasarkan lapisan pendapatan di Desa Tamansari, Kecamatan Licin tahun 2017

Modal fisik yang dimiliki rumahtangga penambang belerang pada lapisan bawah bernilai rendah. Rendahnya pendapatan yang diperoleh rumahtangga penambang belerang pada lapisan ini menyebabkan rumahtangga tidak memiliki banyak aset yang berharga. Modal fisik rumahtangga penambang belerang lapisan menengah bernilai sedang. Rumahtangga pada lapisan ini memiliki asset yang lebih banyak jumlahnya dibandingkan dengan rumahtangga pada lapisan bawah, namun aset rumahtangga yang mereka miliki tergolong 
sederhana dan seperlunya. Modal fisik yang dimiliki rumahtangga penambang belerang pada lapisan atas bernilai tinggi. Berbeda dengan rumahtangga penambang lapisan menengah yang aset rumahtangganya tergolong sederhana (barang bekas), aset rumahtangga yang dimiliki oleh rumahtagga lapisan atas merupakan barang baru, namun kepemilikannya juga berdasarkan keperluan yang dibutuhkan oleh rumahtangga.

Modal finansial pada rumahtangga lapisan bawah bernilai rendah. Hal ini dikarenakan pendapatan yang diperoleh rumahtangga tergolong rendah. Rumahtangga penambang belerang pada lapisan menengah memiliki modal finansial bernilai sedang. Pendapatan yang diperoleh ruamhtangga baik yang berasal dari kegiatan pertambangan maupun nonpertambangan termasuk pada kategori sedang. Modal finansial yang dimiliki rumahtangga lapisan atas jauh berbeda dengan yang dimiliki rumahtangga lapisan bawah dan menengah. Modal finansial yang dimiliki rumahtangga pada lapisan atas berniali tinggi. Hal ini dikarenakan jumlah pendapatan yang diperoleh rumahtangga tergolong tinggi.

Rumahtangga pada lapisan bawah memiliki modal manusia dengan nilai rendah. Modal manusia yang dimiliki oleh rumahtangga pada lapisan menengah memiliki nilai sedang dan rumahtangga penambang belerang pada lapisan atas memiliki modal manusia bernilai tinggi.

Modal sosial yang dimiliki oleh rumahtangga penambang belerang pada lapisan bawah bernilai rendah, pada lapisan menengah bernilai sedang dan pada lapisan atas bernilai tinggi. Tingkat kepercayaan yang dimiliki oleh rumahtangga penambang belerang baik pada lapisan bawah, menengah, maupun atas memiliki kecenderungan pada kategori timggi. Rata-rata penambang menceritakan satu jenis masalah yang dialami oleh rumahtangga kepada rumahtangga lainnya, baik tetangga maupun saudara. Kepercayaan yang terbangun dengan baik mampu menjadi pelindung bagi rumahtangga terutama ketika terjadi krisis di saat rumahtangga membutuhkan bantuan untuk menghadapi krisis tersebut, seperti halnya meminjam uang.

\section{Pemanfaatan Livelihood Assets yang Mempengaruhi Tingkat Variasi Strategi Nafkah Rumahtangga Penambang Belerang}

Pemanfaatan livelihood assets yang mempengaruhi tingkat variasi strategi nafkah rumahtangga penambang belerang di Desa Tamansari diuji dengan analisis regresi linier. Alpha ditentukan sebesar 20\% atau 0.2 artinya toleransi kesalahan pada uji regresi tersebut adalah $20 \%$ dan kebenarannya adalah $80 \%$. Uji regresi linier dilakukan dengan memenuhi empat asumsi regresi yaitu (1) sisaan menyebar normal, (2) tidak ada multikolinieritas, (3) ragam sisaan homogen (homoskedositas), dan (4) kebebasan sisaan.

Hasil analisis regresi dengan tingkat signifikan $(\mathrm{p}<$ 0.2) menunjukkan bahwa variabel yang mempengaruhi tingkat variasi strategi nafkah rumahtangga penambang belerang. Apabila nilai prob. t hitung (pada tabel ditunjukkan pada kolom sig) lebih kecil dari tingkat kesalahan (alpha) 0.2 maka dapat dikatakan bahwa variabel bebas (dari $\mathrm{t}$ hitung tersebut) berpengaruh signifikan terhadap variabel terikatnya. Berdasarkan hasil analisis regresi dapat disimpulkan bahwa variabel tingkat modal sosial rumahtangga berpengaruh secara signifikan terhadap tingkat variasi strategi nafkah rumahtangga penambang belerang. Berdasarkan hasil regresi yang diperoleh, maka persamaan regresi dapat ditulis sebagai berikut:

$\mathrm{Y}=0.886+0.277 \mathrm{X}_{5}$

Koefisien determinasi menjelaskan variasi pengaruh variabel-variabel bebas terhadap variabel terikatnya, atau dapat dikatakan sebagai proporsi pengaruh seluruh variabel bebas terhadap variabel terikatnya. Nilai koefisien determinasi dapat diukur oleh nilai $R$ Squere. Diketahui bahwa nilai $R$-Squere yang diperoleh sebesar 0.332 atau $33,2 \%$. Hal ini berarti modal sosial memiliki proporsi pengaruh terhadap strategi nafkah sebesar $33.2 \%$ sedangkan sisanya $66.8 \%$ dipengaruhi oleh variabel ataupun faktor lain yang tidak ada di dalam model regresi linier sehingga model regresi yang diperoleh hanya mampu menjelaskan sebanyak $33.2 \%$. 
Berdasarkan nilai koefisien b maka diketahui bahwa setiap penambahan satu modal sosial maka terjadi penambahan pula pada strategi nafkah sebesar 0.277. Variabel tingkat modal sosial berpengaruh signifikan dengan tingkat variasi strategi nafkah rumahtangga penambang belerang. Semakin tinggi tingkat modal sosial rumahtangga maka semakin tinggi tingkat variasi strategi nafkah yang dijalankan oleh rumahtangga penambang belerang.

\section{SIMPULAN DAN SARAN}

\section{Simpulan}

Hasil penelitian tentang strategi nafkah dan modal sosial rumahtangga penambang belerang di Desa Tamansari merumuskan kesimpulan sebagai berikut:

1. Struktur nafkah rumahtangga penambang belerang di Desa Tamansari disusun oleh pendapatan menambang dan non-menambang. Berdasarkan pendapatan yang diperoleh, rumahtangga penambang belerang dapat dibedakan menjadi tiga lapisan, yaitu lapisan bawah, lapisan menengah dam lapisan atas. Kategori penambang belerang yang berada pada lapisan atas memiliki struktur pendapatan, struktur pengeluaran, dan kapasitas menabung yang lebih tinggi dibandingkan dengan kategori penambang belerang pada lapisan menengah dan bawah. Selain itu jika dilihat dari pendapatan per kapita per hari setiap lapisan rumahtangga penambang belerang di Desa Tamansari baiik pada lapisan bawah, lapisan menengah, dan lapisan atas telah berada di atas garis kemiskinan menurut World Bank yaitu memiliki pendapatan diatas $\$ 2.00$ per kapita per hari.

Setiap rumahtangga penambang belerang melakukan berbagai macam strategi nafkah untuk memenuhi kebutuhan hidupnya. Strategi nafkah yang digunakan oleh rumahtangga penambang belerang di Desa Tamansari yaitu strategi bertahan hidup dengan mengadopsi berbagai aktivitas ekonomi, pola nafkah ganda, migrasi, pemanfaatan jaringan sosial, mempekerjakan anggota rumahtangga, berhutang dan mengganti jenis makanan. Setiap rumahtangga memiliki strategi nafkah yang berbeda-beda berdsarkan kategori rumahtangga. Strategi pola nafkah ganda dan strategi pemanfaatan jaringan sosial dilakukan oleh seluruh lapisan rumahtangga penambang belerang. Strategi migrasi dilakukan oleh sebagian rumahtangga penambang belerang pada lapisan bawah. Mayoritas rumahtangga penambang belerang di Desa Tamansari melakukan strategi nafkah berhutang untuk dapat memenuhi kebutuhan hidup, namun mayoritas pada rumahtangga lapisan menengah dan atas berhutang kepada pihak perbankan, sementara pada rumahtangga lapisan bawah dan beberapa rumahtangga lapisan menengah memilih untuk berhutang kepada tetangga atau pun warung. Strategi mengganti jenis makanan mayoritas dilakukan oleh rumahtangga penambang belerang, strategi ini dipilih ketika rumahtangga sedang mengalami krisis khususnya krisis ekonomi.

2. Setiap lapisan rumahtangga penambang memiliki kecenderungan terhadap pemanfaatan modal nafkah yang berbeda-beda. Modal alam pada rumahtangga bawah bernilai rendah, pada rumahtangga lapisan menengah bernilai sedang, sedangkan pada rumahtangga lapisan atas bernilai tinggi. Modal finansial pada rumahtangga lapisan bawah bernilai rendah, sedangkan pada rumahtangga lapisan menengah bernilai sedang dan atas bernilai tinggi. Modal manusia yang dimanfaatkan oleh rumahtangga lapisan rendah bernilai rendah, sementara pada rumahtangga lapisan menengah bernilai sedang dan pada lapisan atas bernilai tinggi. Modal fisik pada rumahtangga lapisan bawah bernilai rendah, sementara pada rumahtangga lapisan menengah bernilai sedang dan pada lapisan atas bernilai tinggi. Modal sosial pada rumahtangga penambang belerang lapisan bawah bernilai rendah, lapisan menengah bernilai sedang dan lapisan atas bernilai tinggi. Sementara itu, modal sosial berpengaruh secara signifikan terhadap strategi nafkah, sedangkan modal alam, modal finansial, modal manusia dan modal fisik tidak berpengaruh secara signifikan terhadap strategi nafkah rumahtangga penambang belerang di Desa Tamansari, Kecamatan Licin, Kabupaten Banyuwangi, Provinsi Jawa Timur.

\section{Saran}

Pemerintah diharapkan mampu untuk memahami segala permasalahan yang dihadapi oleh para penambang belerang dan mampu untuk memberikan perhatian lebih kepada para pelaku usaha penambangan belerang khususnya dalam hal 
pemberian pelatihan keterampilan dan keselamatan kerja mengingat usaha penambangan belerang merupakan pekerjaan yang berat karena dalam melakukan pekerjaan ini mereka harus mempertaruhkan jiwa dan raga mereka. Maka dari itu dengan memahami segala hal terkait dengan penambangan belerang serta permasalahan yang mereka hadapi, pemerintah diharapkan dapat merumuskan kebijakan yang tepat untuk pelaku sektor informal khususnya penambang belerang ini. Bagi pihak perusahaan pengelola penambangan belerang di Gunung Ijen agar lebih memperhatikan para pekerja tambangnya terutama mengenai peralatan keselamatan kerja dan upah kerja penambang.

\section{DAFTAR PUSTAKA}

Astuti S. 2012. Pola Relasi Sosial Petani dengan Buruh Tani dalam Produksi Pertanian (studi deskriptif masyarakat Desa Tanjung Rejo, Kecamatan Percut Sei Tuan, Kabupaten Deli Serdang, Sumatra Utara). Medan (ID): Universitas Sumatra Utara.

Dharmawan AH. 2001. Farm household livelihood strategies and socioeconomic changes in rural indonesia. Kiel (DE): Wissenschaftsverlag Vauk Kiel KG.

Dharmawan, AH. 2007. Sistem Penghidupan dan Nafkah Pedesaan: Pandangan Sosiologi Nafkah (Livelihood Sociology) Mazhab Barat dan Mazhab Bogor. Sodality: Jurnal Transdisiplin Sosiologi, Komunikasi dan Ekologi. [Internet]. [diunduh 2016 November 23]. 1 (2): 169-192. Tersedia pada:

http://ejournal.skpm.ipb.ac.id/index.php/sod ality/article/view/137/132.

Dharmawan AH, Manig W. 2000. Livelihood Strategies and Rural Changes in Indonesia; Studies on Small Farm Communities. Deutscher Tropentag 2000 in Hohenheim. Session: Assessment of Proverty and Livelihood Strategies. Germany: Institute of Rural Development the University of Goettingen Germany, Hal. 1-9.

Ellis F. 2000. Rural Livelyhood and Diversity In Developing Countries. New York (US): Oxford University Press.
Scoones. 1998. Sustainable Rural Livelihoods a Framework for Analysis. IDS Working Paper: 72. Brighton (UK): Institute for Development Studies. [Internet]. [diunduh 2016 September 20]. Tersedia pada: graduateinstitute.ch/

files/livesites/iheid/files/sites/developpement /shared/developpement/mdev/soutienauxcou rs 0809/Gironde\%20Pauvrete/Sustainable $\% 2$ 0Rural\%20Livelihhods\%20$\% 20$ Scoones.pdf

Scott JC. 1976. The Moral Economy of the Peasant: Rebellion and Subsistance in Southeast Asia. New Heaven: University Press.

Sembiring ST, Dharmawan AH. 2014. Resiliensi Nafkah Rumahtangga Petani di Kawasan Rawan Bnecana ROB Kecamatan Kampung Laut, Kabupaten Cilacap. Sodality: Jurnal Transdisiplin Sosiologi, Komunikasi dan Ekologi. [Internet]. [diunduh 2016 September 20]. 2 (1): 30-42. Tersedia pada: http://journal.ipb.ac.id/index.php/sodality/art icle/view/9410/7374.

Singarimbun M, Effendi S. 2012. Metode Penelitian Survei. Jakarta (ID): LP3ES 
Afqari \& Dharmawan /Jurnal Sains Komunikasi dan Pengembangan Masyarakat 2(4): 551-566

566 - Agustus 2018 